\title{
Model-view-controller approach for e-Zakah
}

\author{
Ah. Fathonih ${ }^{1}$, Dian Sa'adillah Maylawati ${ }^{2}$, Muhammad Ali Ramdhani ${ }^{3}$ \\ ${ }^{1}$ Department of Islamic Law, UIN Sunan Gunung Djati Bandung, Indonesia \\ ${ }^{2,3}$ Faculty of Information and Communication Technology, Universiti Teknikal Malaysia Melaka, Malaysia \\ ${ }^{3}$ Department of Informatics, UIN Sunan Gunung Djati Bandung, Indonesia
}

\begin{tabular}{l} 
Article Info \\
\hline Article history: \\
Received Sep 21, 2018 \\
Revised Jan 07, 2019 \\
Accepted Mar 15, 2019 \\
\hline Keywords: \\
e-Zakah \\
Model-view-controller \\
Software analysis \\
Software design \\
Software traceability \\
Unified modeling language \\
Zakah
\end{tabular}

\begin{abstract}
Zakah (alms) has a strategic position in terms of Islamic value and terms of the development of the welfare of the people. In the current digital era, the use of technology can facilitate zakah worship more easily, quickly, efficiently, and secure. This study aims to analyze and design electronic zakah (e-Zakah) structurally and systematically using the Model-ViewController (MVC) approach. MVC is an approach or pattern of objectoriented analysis and design for software development that widely used today. MVC is implemented in the analysis and design modelling using Unified Modeling Language (UML) for e-Zakah. Based on the traceability result of analysis and design of e-Zakah, it can be concluded that the e-Zakah analysis and design model has been met all of zakah concept, user and software requirements, and all of models can be traced to each other. Therefore, e-Zakah analysis and design model in this study is ready to be built as a software.
\end{abstract}

Copyright (0) 2019 Institute of Advanced Engineering and Science. All rights reserved.

Corresponding Author:

Ah. Fathonih,

Department of Islamic Law,

UIN Sunan Gunung Djati Bandung,

Jl. A.H. Nasution 105, Bandung, 40614, Indonesia.

Email: ah.fathonih@uinsgd.ac.id

\section{INTRODUCTION}

In the digital and internet of things era, Information System such as e-Commerce, e-Banking, eCounseling and in this study that propose e-Zakah become an important and interesting thing to develop. IS which are a combination of information technology and human activities that use computerized technology [1], can be used to support decision making [2], manage the organized data [3], that built based on user requirements [4], capable of solving complex data [5], and IS have a high degree of flexibility that allows to be developed into better systems [6]. Based on much previous research, IS has advantages such as accurate [7], precise support decision [8], good data accessibility [9], efficient processing time [10], more economical [11], improve productivity [12], present data and information well [13], widely used [14], improve user understanding [10], and as media to save data [15].

e-Zakah deserves to be developed as a strategic effort of zakah marketing [16]. Currently, in Indonesia, e-Zakah has not independent yet, it still joins e-Commerce (such as Elevenia.com) or e-Banking (such as BNI/ Bank Negara Indonesia Mobile Banking and BRI/ Bank Rakyat Indonesia Mobile Banking). e-Zakah will provide convenience for muzakki (the person who carry out zakah) in paying zakah. Besides that, e-Zakah also has many advantages, among others: providing convenience to muzakki in paying zakah, compared to manual payments in offices (Amil Zakah Institution); making zakah closer to the community, because the zakah payment system is easy and commonly used by the community; the performance of Amil Zakah (committees who manage zakah), looks more professional, the impact is public trust in the performance of amil is higher; between amil Zakah Institution branches and zakah mobile counters can now be connected in one online network; between amil zakah institution and zakah mobile counters can now be 
connected each other in one online networks. However, the lack of e-Zakah still needs to be considered, these deficiencies are risks and consequences that must be borne in the development of the e-Zakah system. The attitude of community prudence is needed in the use of this e-Zakah facility. In addition, cooperation from various related parties is also needed, in addition to building a perfect e-Zakah network system but also to anticipate the risks that will occur.

To anticipate the various weaknesses of e-Zakah, detailed system analysis and design is needed so that all of user and system requirements are reached. Not many previous studies that discuss about optimization of zakah using technology, one of study that related is about predicting the usage of e-Zakah in Selangor, Malaysia using unified theory of acceptance and use of technology model [17], but the research did not explain how to develop the e-Zakah based on software engineering, only examine the extent of utilization of an online e-Zakah. Therefore, this study presents the analysis and design model structurally and systematically for e-Zakah using UML that implemented MVC pattern. The result of this study is an analysis and design model that ready to implement into e-Zakah software, either in web-based, mobile-based, or desktop. It In the next session, it is described the methodology that used in this study, result and discussion that contains the analysis of zakah including the calculation of zakah, user and e-Zakah requirements analysis, and analysis and design modeling for e-Zakah. Then, the last session describes the conclusion of this study.

\section{RESEARCH METHOD}

The methodology used in this study is described with the flowchart in Figure 1. Begin from understanding the concept of zakah, among others: the definitions, who is obliged to pay zakah, who is entitled to receive zakah, what properties that can be shared as zakah, and also how is the calculation and distribution of zakah. Then, from the concept will be analyzed as requirement elicitation process which is collect the detail information about the needs of user (muzzaki), needs of recipient zakah, needs of amil zakah, and requirement of the system. All of the requirements in the analysis phase is modelled using UML, and also in the design phase.

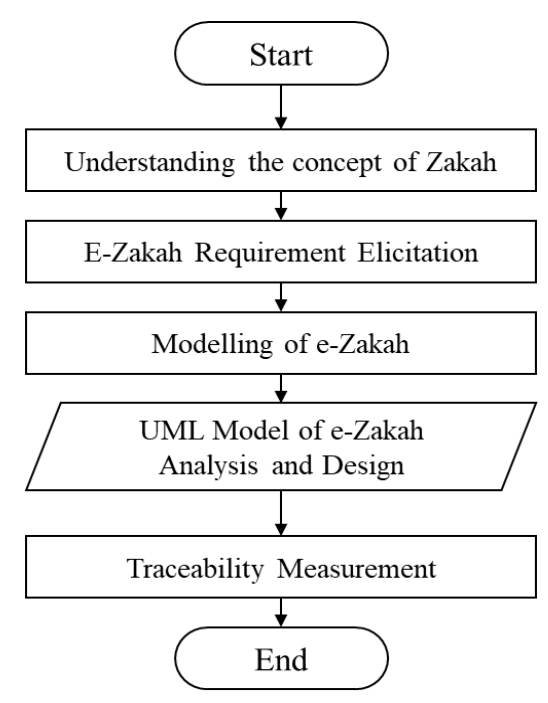

Figure 1. Flowchart of e-Zakah Analysis and Design

The analysis and design model for e-Zakah, besides using UML, it also uses MVC approach or pattern, that classifies the object as the model, view, and controller [18-19]. Model is an object collection which functions to store data and object information, view or boundary is an object collection that used for an object accessed by the user as an interface, while the controller is the object collection that connects between model and view. Therefore, models and views are not allowed to interact directly, must go through the controller. The analysis and design model of e-Zakah in this study can be used for whatever software development life cycle (SDLC) or software development method. Either the conventional SDLC such as Waterfall, Prototype, Iterative, Spiral, or so on [20-22]. The recommendation SDLC that can be used is the Rational Unified Process (RUP) that uses UML as a model [20], [23-24]. 
Moreover, it also can be used Agile Methodology, such as Scrum, Xtream Programming (XP), and so on [25-28]. To maintain the quality of analysis and design model of e-Zakah, it is also measured the traceability between requirement and model, and between model to each other. This traceability measurement makes sure that all of the requirement is reached and the connectivity between model is according to expectations [9], [29-30]. Reliability of e-Zakah in this article, it is used: analytical, logical, conceptual, and operational verification by an expert [31].

\section{RESULTS AND ANALYSIS}

\subsection{The Concept of Zakah}

In the Holy Qur'an, the letter At-Taubah verse 34, Az-Zariyat verse 19, and Al-Ma'un verse 1-2, states that zakah is compulsory worship and the third principle of the pillars of Islam. In addition to the Qur'an, there are several narrations of hadith which are used as the basis for obligatory zakah, among others: "Allah obliges them (the Yemenis) to zakah on their wealth, zakah is taken from rich people and distributed to the poor" [32]. Even the Prophet said that issuing zakah is sacred and purifying, connecting relationship with relatives, neighbors, beggars, and respecting the rights of the poor [33]. There are three actors that are related directly in the zakah worship, among others muzzaki, mustahiq, and amil. Muzzaki is a person who gives zakah, mustahiq is a person who receives zakah, and amil is a person or institution that manage and distribute the property of zakah. In carrying out zakah, there are terms and conditions that must be fulfilled relating to muzzaki, mustahiq, and property that can be given as zakah.

\subsection{Types and Calculation of Zakah}

There are several types of zakah, and each type has adifferent calculation. The types and calculation of zakah are among others:

\subsubsection{Zakah Fitrah (Al-Fitr)}

Zakah Al-Fitr is a charity that is fulfilled by every Muslim, male or female in order to purify the soul (zakah al-nafs). Every individual, whether adult or not, is obliged to pay zakah fitr, whose implementation is at the same time or after the fasting month of Ramadan. In Indonesia, zakah fitr is measured by $2.5 \mathrm{~kg}$ of rice [34].

\subsubsection{Zakah Mal}

Zakah mal is zakah of wealth, it means zakah issued from wealth or the source of wealth itself. The wealth that for zakah mal are among others:

a. Gold and Silver. The main requirement for gold and silver zakah is to reach nisab and have passed one year. Based on the hadith narrated by Abu Dawud, the nisab of gold zakah is twenty misqal or twenty dinars while the nisab of silver zakah is two hundred dirhams. Twenty misqals or two dinars, according to Yusuf Qardhawi, are 85 grams of gold, two hundred dirhams equal to 595 grams of silver [35]. So, for gold and silver zakah which are reached the nisab, it is compulsory zakah $2.5 \%$ of savings gold and silver that owned.

b. Plants and Fruits. Nisab of plants and fruit from an agricultural product, such as paddy farming is minimal $653 \mathrm{~kg}$, while if the agricultural products are in the form of fruits, vegetables, and flowers so that all agricultural wealth is converted to the value of the local staple food agriculture. For the agriculture that uses rainwater, river water, and springs as sources of irrigation, if the managed rice fields are rainfed rice fields and other types of irrigation that do not need to buy water, then the amount of zakah from agricultural produce is $10 \%$ of all crops. But, if the agriculture that requires buying irrigation water so that their fields can grow, for this type of agriculture the amount of agricultural zakah that must be spent is 5\% of all crops [36].

c. Commercial property. Nisab of commercial property as specified in gold and silver were taken from the sale price. Thus the zakah is $2.5 \%$ [37]. Most of the scholars argued that the assets of commerce were obligatory in zakah, so the zakah rate of $2.5 \%$ from nisab was 20 dinars or worth with 85 gr of gold.

d. Cattle: describes in Table 1

e. Rikaz (found items) and mining goods. Regarding assets that must be given for zakah from hidden assets or treasure or found items or rikaz, the zakah is one fifth or $20 \%$, with the note that the property that is found on land that has no owner.

\subsubsection{Zakah of Profession}

Professional zakah is not yet familiar in the classical Islamic scholarship. Therefore, the results of the profession are categorized as the type of obligatory property of zakah based on analogy on the similarity 
(syabbah) of the characteristics of the existing zakah property, namely [38]: (1) the model of earning income (profession) is similar to harvest (agricultural produce), so this property can be attributed to agricultural zakah based on nisab (653 kg of dry milled rice or equivalent to $522 \mathrm{~kg}$ of rice) and the time of zakah (each harvest); (2) the model of assets received as income in the form of money, so that this type of property can be attributed to the zakah of assets (savings or wealth) based on the level of zakah that must be paid $(2.5 \%)$. Thus, if a person's professional results have fulfilled the requirements of zakah, he is obliged to pay his zakah.

Table 1. Nisab of Cattle Zakah [35], [39]

\begin{tabular}{|c|c|c|c|}
\hline No. & Cattle & Nisab & Zakah Obligation \\
\hline \multirow[t]{11}{*}{1} & Camel & 5 & 1 goat 2 years old, or 1 sheep 1 year old \\
\hline & & 10 & 2 goats 2 years old, or 2 sheep old 1 year \\
\hline & & 15 & 3 goats old 2 years, or 3 sheep old 1 year \\
\hline & & 20 & 4 goats 2 years old, or 4 sheep 1 year old \\
\hline & & 25 & 1 female camel 1 year old \\
\hline & & 36 & 1 female camel 2 years old \\
\hline & & 46 & 1 female camel 3 years old \\
\hline & & 61 & 1 female camel 4 years old \\
\hline & & 76 & 2 female camels 2 years old \\
\hline & & 91 & 2 female camels 3 years old \\
\hline & & 121 & 3 female camels 2 years old \\
\hline \multirow[t]{2}{*}{2} & Cow & 30 & 1 cow 1 year old \\
\hline & & 40 & 1 cow 2 year old \\
\hline \multirow[t]{4}{*}{3} & Goat & 40 & 1 goat 2 years old, or 1 sheep 1 year old \\
\hline & & 121 & 2 goats 2 years old, or 2 sheeps 1 year old \\
\hline & & 201 & 3 goats 2 years old, or 3 sheeps 1 year old \\
\hline & & 400 & 4 goats 2 years old, or 4 sheeps 1 year old \\
\hline
\end{tabular}

\subsubsection{E-zakah requirements analysis}

According with the concept of zakah, we find all of e-Zakah functional requirements in the Table 2 and non-functional requirements in Table 3. Then, the requirement analysis of e-Zakah is modeled by use case diagram in Figure 2 with list of use case code number in Table 4. In general, requirements is gotten from the needs of stakeholders (muzzaki, mustahiq, amil, and administrator) and from business process of zakah, begin from identifying the personal data of muzzaki, mustahiq, and amil, then and ensure they fulfill the mandatory and legal requirements for zakah, especially for muzzaki and mustahiq. Because not to zakat distributed to people who are not right. Arter identifying the stakeholders, then conduct the business process of zakah, what is the type of zakah that will be chosen, whether the property that will be zakat has fulfilled the conditions of the provisions, the haul and the nisab. If all of the requirements have been met, then the system will automatically calculate how much zakat must be issued by muzzaki. Then, the system will offer several payment options both online and offline. Amil must ensure the distribution of zakat to mustahiq goes well. The flow of zakat from muzzaki to mustahiq is all managed in the system, as well as the history of revenues and expenditures of zakah. Class Diagram of E-Zakah as shown in Figure 3.

Table 2. E-Zakah Functional Requirements Analysis

\begin{tabular}{|c|c|}
\hline ID Req. & Description of Requirement \\
\hline FR-Z-01 & e-Zakah provides the information about the concept and type of zakah as a knowledge for the community. \\
\hline FR-Z-04 & $\begin{array}{l}\text { e-Zakah shows the types of zakah which can be selected, among others: zakah fitrah, zakah mal (gold and silver), } \\
\text { zakah mal (plants and fruits), zakah mal (cattle), zakah mal (commercial property), zakah mal (rikaz), and zakah of } \\
\text { profession. }\end{array}$ \\
\hline FR-Z-06 & e-Zakah able to calculate the nominal or the amount of zakah based on the types of zakah. \\
\hline FR-Z-07 & $\begin{array}{l}\text { e-Zakah provides payment facilities both online and offline (if muzzaki wants to deliver directly to the } z a k a h \\
\text { institution). }\end{array}$ \\
\hline FR-Z-11 & e-Zakah provides the form and fuction to support amil in distributing zakah for mustahiq. \\
\hline
\end{tabular}




\begin{tabular}{ll}
\hline ID Req. & \multicolumn{1}{c}{ Description of Requirement } \\
\hline FR-Z-12 & e-Zakah provides report form that contain muzzaki and mustahiq profile for amil. \\
FR-Z-13 & e-Zakah provides the facility for amil to manage muzzaki and mustahiq data. \\
FR-Z-14 & e-Zakah provides the report history of revenues and expenditures of zakah from muzzaki to mustahiq. \\
FR-Z-15 & e-Zakah provides control panel for administrator manage all of activites and data during zakah process. \\
\hline
\end{tabular}

Table 3. E-Zakah Non-Functional Requirements Analysis

\begin{tabular}{cl}
\hline ID Req. & \multicolumn{1}{c}{ Description of Requirement } \\
\hline NFR-Z-01 & e-Zakah provides security system for user authentification with password encryption, at least md5. \\
NFR-Z-02 & e-Zakah has availibility 24 hours. \\
NFR-Z-03 & e-Zakah has a back up data if the server that is used down. \\
NFR-Z-04 & $\begin{array}{l}\text { e-Zakah can generate all of report both data personal report and zakah activity report no more than five minutes } \\
\text { of processing time. }\end{array}$ \\
NFR-Z-05 & $\begin{array}{l}\text { e-Zakah provides data sequrity for zakah payment process. } \\
\text { NFR-Z-06 }\end{array}$ \\
& e-Zakah send the notification of each urgent zakah activity (such as payment process), both in system and \\
\end{tabular}

Table 4. E-Zakah Use Case Code Number

\begin{tabular}{|c|c|c|c|}
\hline Use Case Code & Use Case Name & Use Case Code & Use Case Name \\
\hline UC-Z-01 & Information of Zakah Concept & UC-Z-16 & Choose Online Payment \\
\hline UC-Z-02 & Registration & UC-Z-17 & Upload Proof of Payment File \\
\hline UC-Z-03 & Choose Type of Zakah & UC-Z-18 & Generate Payment Reference Number \\
\hline UC-Z-05 & Choose Zakah Mal (Gold and Silver) & UC-Z-20 & Manage Mustahiq, Amil, and Muzzaki Data \\
\hline UC-Z-06 & Choose Zakah Mal (Cattle) & UC-Z-21 & Manage and Control Zakah Log Activities \\
\hline UC-Z-09 & $\begin{array}{l}\text { Choose Zakah Mal (Commercial } \\
\text { Property) }\end{array}$ & UC-Z-24 & Distribute Zakah \\
\hline UC-Z-10 & Choose Zakah of Profession & UC-Z-25 & Get Payment Notification \\
\hline UC-Z-11 & $\begin{array}{l}\text { Identifying Haul and Nisab of Zakah } \\
\text { Property }\end{array}$ & UC-Z-26 & Verify Payment Status \\
\hline UC-Z-15 & Choose Offline Payment & UC-Z-30 & $\begin{array}{l}\text { Generate Revenues and Expenditures Report of } \\
\text { Zakah }\end{array}$ \\
\hline
\end{tabular}

\subsection{E-zakah design}

The design of e-Zakah in this study is modeled by class diagram, sequence diagram, and activity diagram. However, in this article only present class diagram with several attribute and method that can be developed based on the needs of implementation and the example of sequence diagram. Because, sequence diagram must be made for each use case, and It is very possible for a use case to have more than one sequence diagram that illustrates the alternative activities of a use case. Class diagram of e-Zakah is presented in Figure 3 with the code number for each class is shown in Table 5, while the example of sequence diagram is presented in Figure 4. Both class diagram and sequence diagram is modeled using MVC approach, which separate between model, view, and controller objects.

Table 5. E-Zakah Class Code Number

\begin{tabular}{clll}
\hline Class Code & \multicolumn{1}{c}{ Class Name } & Class Code & Class Name \\
\hline C-Z-01 & LoginForm & C-Z-18 & ManageDataController \\
C-Z-02 & RegistrationForm & C-Z-19 & ZakahTypeController \\
C-Z-03 & ZakahInformationUI & C-Z-20 & MuzzakiModel \\
C-Z-04 & ZakahTypeUI & C-Z-21 & MustahiqModel \\
C-Z-05 & PaymentForm & C-Z-22 & AminModel \\
C-Z-06 & ReportUI & C-Z-23 & AdministratorModel \\
C-Z-07 & ControlPanelUI & C-Z-24 & ReportModel \\
C-Z-08 & CalculationBoundary & C-Z-25 & LogActivityModel \\
C-Z-09 & MainPage & C-Z-26 & ZakahTypeModel \\
C-Z-10 & LoginController & C-Z-27 & ZakahFitrahModel \\
C-Z-11 & ReportController & C-Z-28 & ZakahMalGoldAndSilverModel \\
C-Z-12 & ZakahCalculationController & C-Z-29 & ZakahMalRikazModel
\end{tabular}

Indonesian J Elec Eng \& Comp Sci, Vol. 15, No. 2, August 2019 : 1054 - 1065 


\begin{tabular}{clll}
\hline Class Code & \multicolumn{1}{c}{ Class Name } & Class Code & \multicolumn{1}{c}{ Class Name } \\
\hline C-Z-13 & PaymentController & C-Z-30 & ZakahMalCattleModel \\
C-Z-14 & NotificationController & C-Z-31 & ZakahMalPlantsAndFruitsModel \\
C-Z-15 & RegistrationController & C-Z-32 & ZakahMalCommercialPropertyModel \\
C-Z-16 & CPanelController & C-Z-33 & ZakahOfProfessionModel \\
C-Z-17 & LogActivityController & & \\
\hline
\end{tabular}

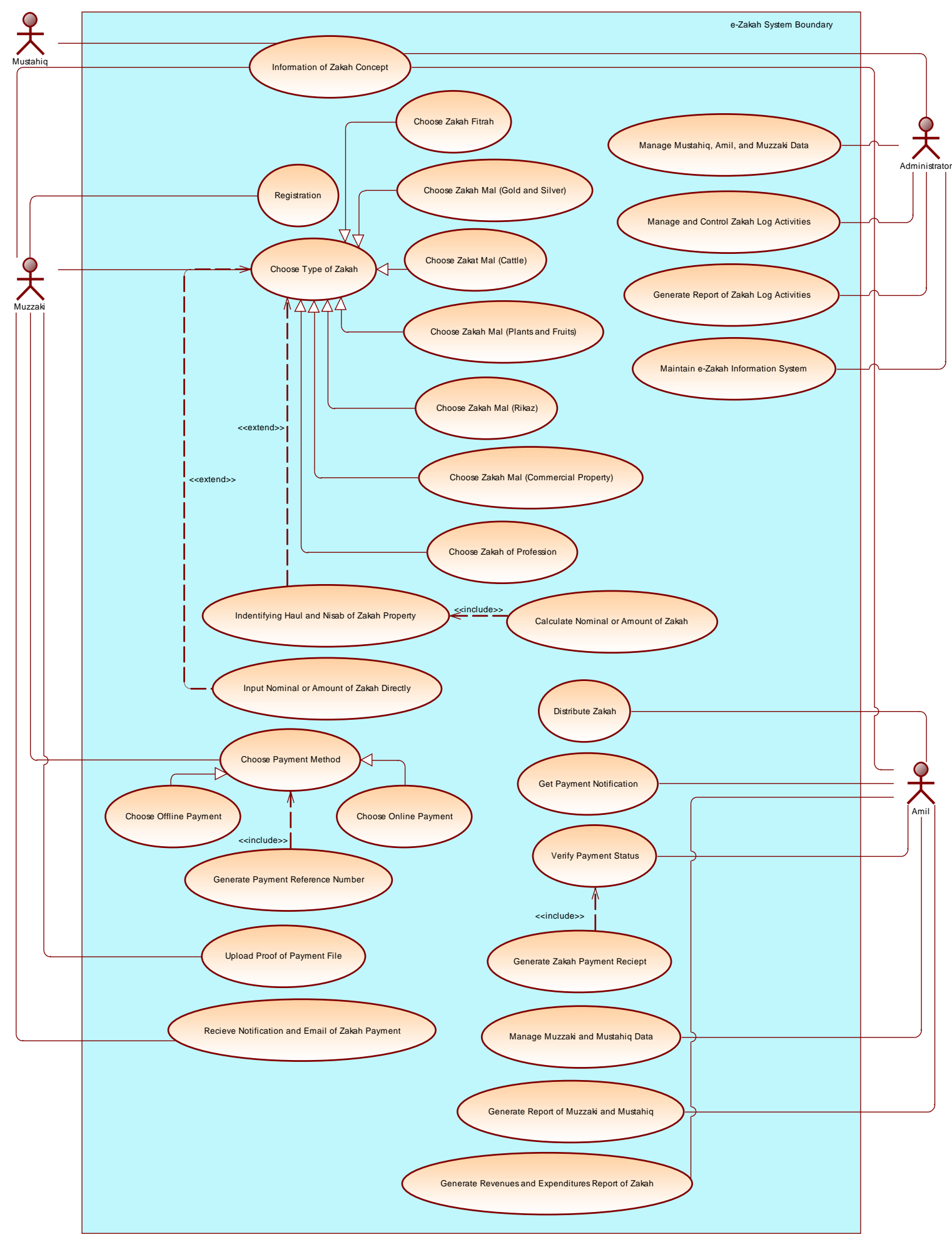

Figure 2. Use Case Diagram of E-Zakah 


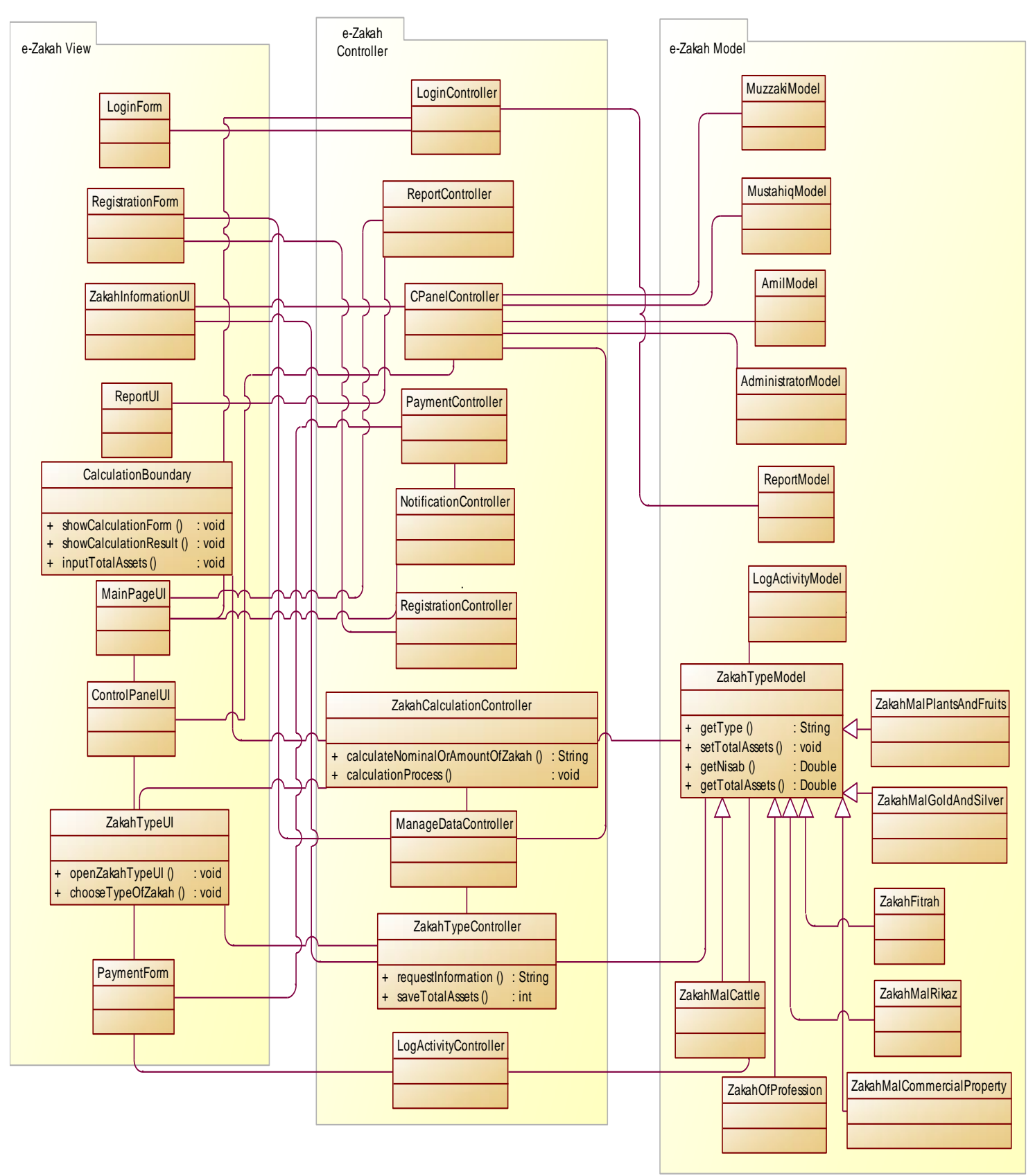

Figure 3. Class Diagram of E-Zakah 


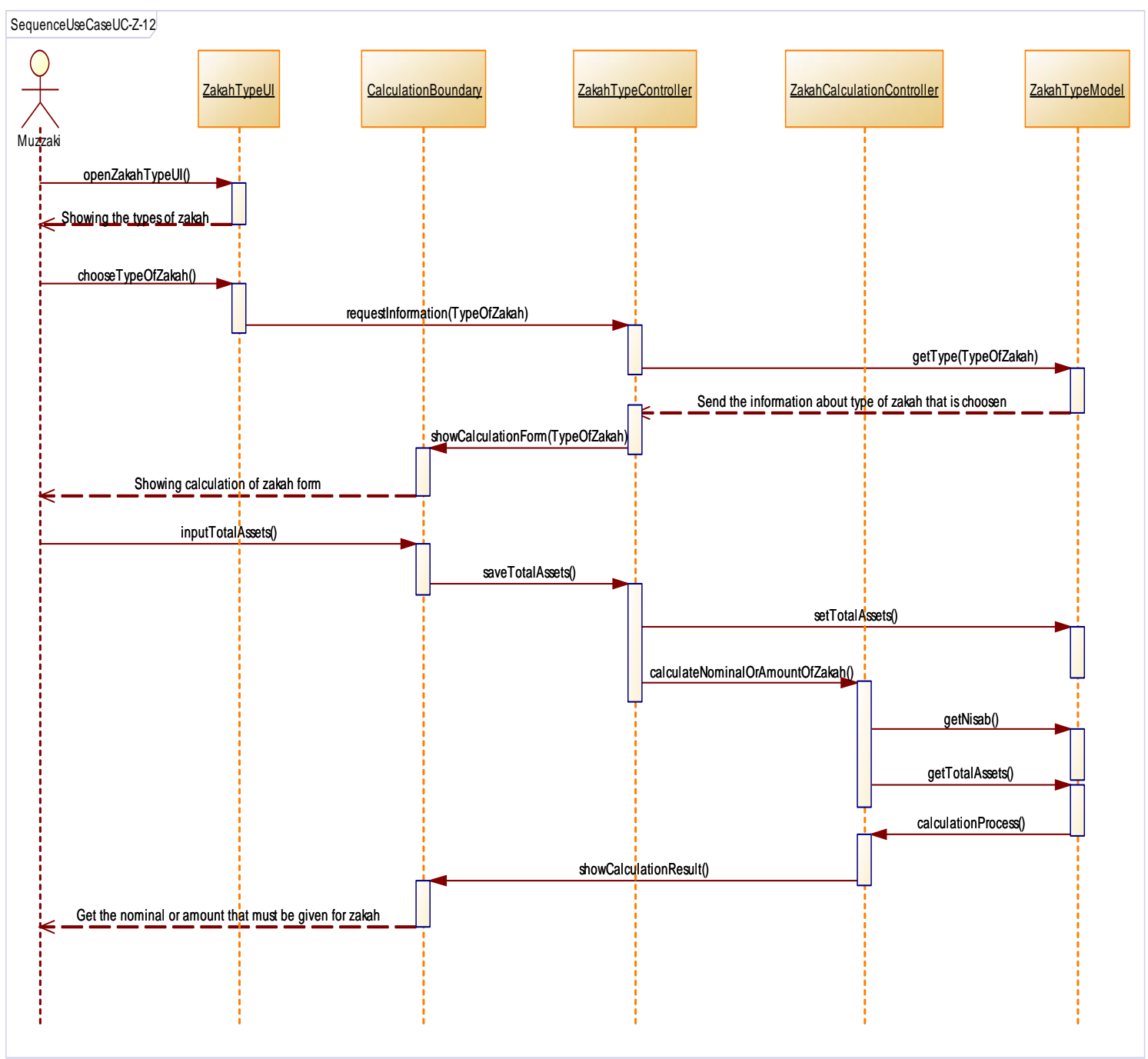

Figure 4. The Example of Sequence Diagram of E-Zakah

\subsection{E-zakah user interface design}

Figures 5-7 describes the example of user interface design for muzzaki in e-Zakah. Figure 5 presents the example of design user interface for information of zakah, Figures 6 and 7 present user interface for zakah mal gold and silver activity.

\begin{tabular}{|c|c|c|c|}
\hline e-Zakah & & & 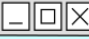 \\
\hline Welcome, Mr. M & & Header - Muzzaki Home Page & Logout \\
\hline Information of & & \multirow{6}{*}{$\begin{array}{l}\text { ZAKAH } \\
\text { Zakah (alms) is a worship that related to property. } \\
\text { Zakah has a strategic position in terms of Islamic teachings } \\
\text { and in terms of the development of the welfare of the people. } \\
\text {... }\end{array}$} & \\
\hline Type of Zakah & $\checkmark$ & & \\
\hline Caclulate Zakal & & & \\
\hline Pay Zakah & & & \\
\hline \multicolumn{2}{|c|}{ History of Zakah Activities } & & \\
\hline \multicolumn{2}{|l|}{ Contact Amil } & & \\
\hline & & Footer & \\
\hline
\end{tabular}

Figure 5. Information of Zakah Design User Interface 


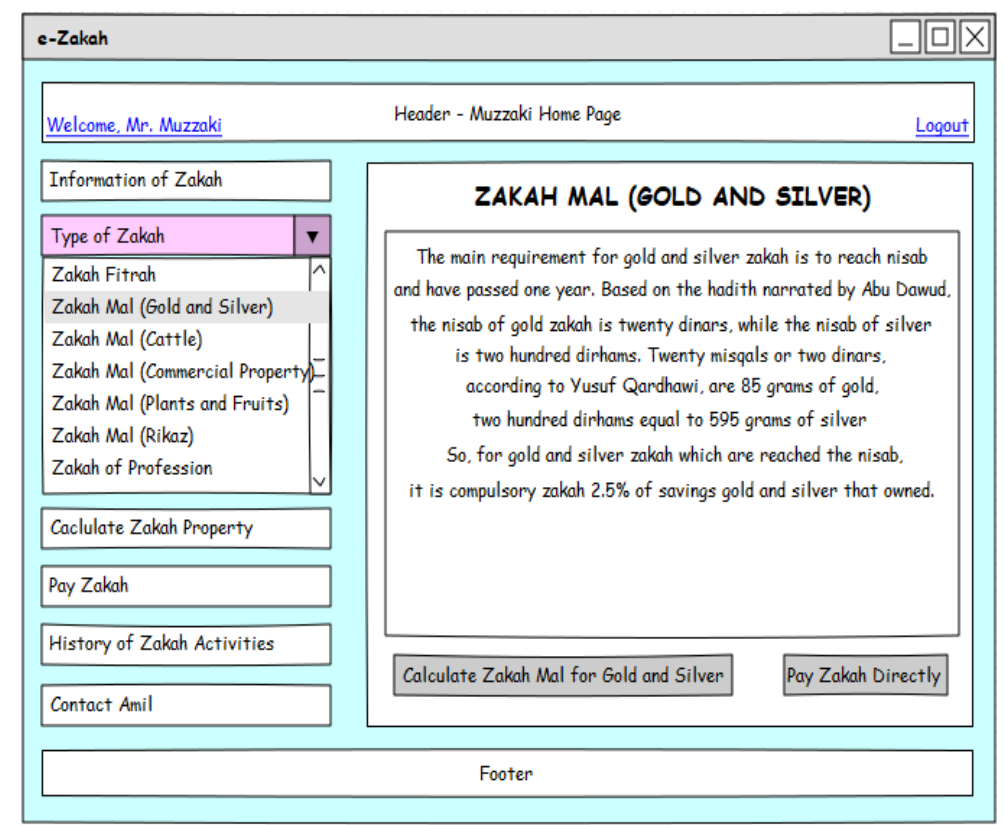

Figure 6. The Example of Sequence Diagram of E-Zakah

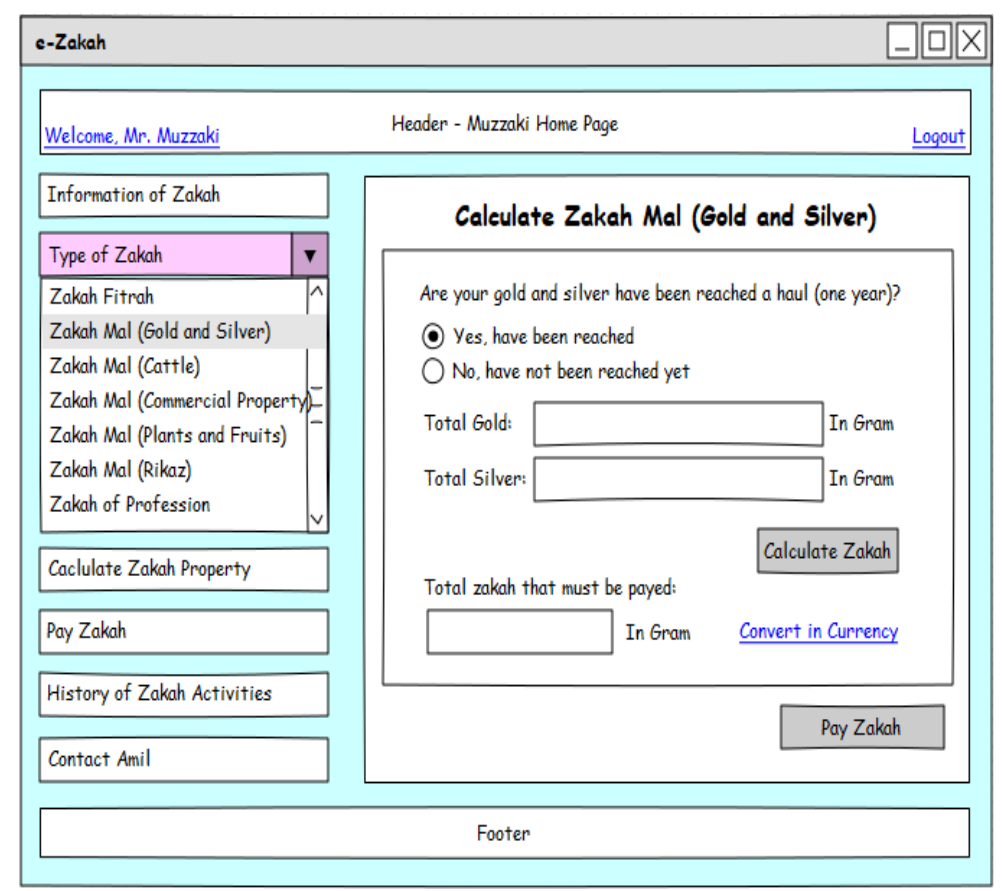

Figure 7. The Example of Sequence Diagram of E-Zakah

\subsection{Traceability of E-Zakah Analysis and Design Model}

The traceability for linkages between functional and non-functional requirements of the analysis and design models is done to ensure that all user and system requirements are met properly. Table 6 provides the result of traceability between functional and non-functional requirements with use case diagram as an analysis model and class diagram as a design model. From Table 6 can be concluded that all of the requirements are met. 
Table 6. Traceability of E-Zakah Analysis and Design Model

\begin{tabular}{|c|c|c|}
\hline Req. Code & Use Case Code & Class Code \\
\hline FR-Z-01 & UC-Z-01, UC-Z-03 & C-Z-03, C-Z-09 \\
\hline FR-Z-02 & UC-Z-02 & C-Z-02, C-Z-09, C-Z-15, C-Z-20, C-Z-21, C-Z-22, C-Z-23 \\
\hline FR-Z-03 & $\begin{array}{l}\text { All of Use Case, except UC-Z-01 and UC-Z- } \\
02\end{array}$ & C-Z-01, C-Z-09, C-Z-10, C-Z-17, C-Z-25 \\
\hline FR-Z-04 & $\begin{array}{l}\text { UC-Z-03, UC-Z-04, UC-Z-05, UC-Z-06, UC- } \\
\text { Z-07, UC-Z-08, UC-Z-09, UC-Z-10 }\end{array}$ & $\begin{array}{l}\text { C-Z-04, , C-Z-09, C-Z-19, C-Z-26, C-Z-27, C-Z-28, C-Z-29, C-Z-30, } \\
\text { C-Z-31, C-Z-32, C-Z-33 }\end{array}$ \\
\hline FR-Z-05 & $\begin{array}{l}\text { UC-Z-03, UC-Z-04, UC-Z-05, UC-Z-06, UC- } \\
\text { Z-07, UC-Z-08, UC-Z-09, UC-Z-10, UC-Z-11, } \\
\text { UC-Z-12, UC-Z-13 }\end{array}$ & $\begin{array}{l}\text { C-Z-04, C-Z-08, C-Z-09, C-Z-12, C-Z-26, C-Z-27, C-Z-28, C-Z-29, } \\
\text { C-Z-30, C-Z-31, C-Z-32, C-Z-33 }\end{array}$ \\
\hline FR-Z-06 & UC-Z-11, UC-Z-12, UC-Z-13 & C-Z-08, C-Z-09, C-Z-12 \\
\hline FR-Z-07 & $\begin{array}{l}\text { UC-Z-14, UC-Z-15, UC-Z-16, UC-Z-18, UC- } \\
\text { Z-19, UC-Z-25, UC-Z-26, UC-Z-27 }\end{array}$ & C-Z-05, C-Z-09, C-Z-13 \\
\hline FR-Z-08 & UC-Z-18, UC-Z-19 & C-Z-09, C-Z-14 \\
\hline FR-Z-09 & UC-Z-17, UC-Z-26 & C-Z-09, C-Z-13 \\
\hline FR-Z-10 & UC-Z-19, UC-Z-25, UC-Z-27 & C-Z-09, C-Z-13, C-Z-14 \\
\hline FR-Z-11 & UC-Z-21, UC-Z-24, UC-Z-28 & C-Z-06, C-Z-09, C-Z-17, C-Z-20, C-Z-21, C-Z-22, C-Z-24, C-Z-25 \\
\hline FR-Z-12 & UC-Z-19, UC-Z-22, UC-Z-29, UC-Z-30 & C-Z-06, C-Z-09, C-Z-11, C-Z-16, C-Z-25, C-Z-24 \\
\hline FR-Z-13 & $\mathrm{UC}-\mathrm{Z}-28$ & C-Z-09, C-Z-18, C-Z-20, C-Z-21 \\
\hline FR-Z-14 & UC-Z-30 & C-Z-06, C-Z-09, C-Z-11, C-Z-24 \\
\hline FR-Z-15 & UC-Z-20, UC-Z-22, UC-Z-23 & C-Z-07, C-Z-09, C-Z-16, C-Z-17, C-Z-25 \\
\hline NFR-Z-01 & \multicolumn{2}{|c|}{ All use cases and classes, except UC-Z-01 and UC-Z-02 } \\
\hline NFR-Z-02 & \multicolumn{2}{|c|}{ All use case and classes } \\
\hline NFR-Z-03 & \multicolumn{2}{|l|}{ All of zakah activities } \\
\hline NFR-Z-04 & $\begin{array}{l}\text { UC-Z-18, UC-Z-19, UC-Z-22, UC-Z-25, UC- } \\
\text { Z-27, UC-Z-29, UC-Z-30 }\end{array}$ & C-Z-06, C-Z-09, C-Z-11, C-Z-14, C-Z-24 \\
\hline FR-Z-20 & All use case and classes & \\
\hline FR-Z-21 & UC-Z-19, UC-Z-25 & C-Z-14 \\
\hline
\end{tabular}

\section{CONCLUSION}

In the technological era many studies could be digitized, one of which was the concept of zakah. This study resulted in making e-Zakah analysis and design using the MVC approach. The MVC approach made the objects easy to be grouped so that they could be meet the modularity quality and were easy to maintain. The e-Zakah analysis and design model which were made using UML had been met all user and system requirements. This result was proven by the results of traceability between functional requirements with the use case diagram as a system analysis model and class diagram as a system design model. Actually, this eZakah analysis and design model can still develop according to implementation requirements. However, because the model uses object-oriented analysis and design, it can be easily implemented using objectoriented programming that is currently widely used. For future research, the implementation and testing of the system both black box and white box can be conducted.

\section{REFERENCES}

[1] A. Pamoragung, K. Suryadi, and M. A. Ramdhani, "Enhancing the Implementation of E-Government in Indonesia through the High-Quality of Virtual Community and Knowledge Portal Design," in European Conference on eGovernment, 2006, pp. 341-348.

[2] M. A. Ramdhani, "Metodologi Penelitian untuk Riset Teknologi Informasi". Bandung: UIN Sunan Gunung Djati Bandung, 2013.

[3] K. Suryadi and M. A. Ramdhani, "Sistem Pendukung Keputusan". Bandung: Remaja Rosdakarya, 2002.

[4] M. A. Ramdhani, D. Sa'adillah Maylawati, A. S. Amin, and H. Aulawi, "Requirements Elicitation in Software Engineering," Int. J. Eng. Technol., vol. 7, no. 2, pp. 772-775, 2018.

[5] W. Darmalaksana, M. A. Ramdhani, R. Cahyana, and A. S. Amin, "Strategic Design of Information System Implementation at University," Int. J. Eng. Technol., vol. 7, no. 2.29, pp. 787-791, 2018.

[6] H. Aulawi, M. A. Ramdhani, C. Slamet, H. Ainissyifa, and W. Darmalaksana, "Functional Need Analysis of Knowledge Portal Design in Higher Education Institution," Int. Soft Comput., vol. 12, no. 2, pp. 132-141, 2017.

[7] U. Syaripuddin, C. Slamet, H. Prabowo, and M. A. Ramdhani, "Design of Decision Support System for Santri Admission," MATEC Web Conf., vol. 197, p. 03010, 2018.

[8] Y. A. Gerhana, W. B. Zulfikar, Y. Nurrokhman, C. Slamet, and M. A. Ramdhani, "Decision Support System for Football Player's Position with Tsukamoto Fuzzy Inference System,” MATEC Web Conf., vol. 197, p. 03014, 2018.

[9] D. Sa'adillah Maylawati, M. A. Ramdhani, and A. S. Amin, "Tracing the Linkage of Several Unified Modelling Language Diagrams in Software Modelling Based on Best Practices," Int. J. Eng. Technol., vol. 7, no. 2, pp. 776-780, 2018.

[10] R. Fauzan, Y. Indrasary, and N. Muthia, "Sistem Pendukung Keputusan Penerimaan Beasiswa Bidik Misi di POLIBAN dengan Metode SAW Berbasis Web,” JOIN (Jurnal Online Inform., vol. 2, no. 2, pp. 79-83, 2017.

[11] A. Rahman, C. Slamet, W. Darmalaksana, Y. A. Gerhana, and M. A. Ramdhani, "Expert System for Deciding a 
Solution of Mechanical Failure in a Car using Case-based Reasoning,” IOP Conf. Ser. Mater. Sci. Eng., vol. 288, no. 1, p. 012011, 2018.

[12] W. B. Zulfikar, Jumadi, P. K. Prasetyo, and M. A. Ramdhani, "Implementation of Mamdani Fuzzy Method in Employee Promotion System," IOP Conf. Ser. Mater. Sci. Eng., vol. 288, no. 1, p. 012147, 2018.

[13] D. S. A. Maylawati, M. A. Ramdhani, W. B. Zulfikar, I. Taufik, and W. Darmalaksana, "Expert system for predicting the early pregnancy with disorders using artificial neural network," in 2017 5th International Conference on Cyber and IT Service Management, CITSM 2017, 2017.

[14] C. Slamet, A. Rahman, M. A. Ramdhani, and W. Darmalaksana, "Clustering the Verses of the Holy Qur'an Using K-Means Algorithm,” Asian J. Inf. Technol., vol. 15, no. 24, pp. 5159-5162, 2016.

[15] A. Taofik, N. Ismail, Y. A. Gerhana, K. Komarujaman, and M. A. Ramdhani, "Design of Smart System to Detect Ripeness of Tomato and Chili with New Approach in Data Acquisition," IOP Conf. Ser. Mater. Sci. Eng., vol. 288, no. 1 , p. 012018, 2018.

[16] Asdin, "E-zakat sebagai Strategi Pemasaran Zakat," Kompasiana, 2017.

[17] N. N. Ahmad, M. Tarmidi, I. U. Ridzwan, M. A. Hamid, and R. A. Roni, "The Application of Unified Theory of Acceptance and Use of Technology ( UTAUT ) for Predicting the Usage of E-Zakat Online System," Int. J. Sci. Res., 2014.

[18] J. Deacon, "Model-View-Controller (MVC) Architecture," Comput. Syst. Dev., pp. 1-6, 2005.

[19] S. Uyun and M. Rifqi, "Implementation of Model View Controller (MVC) Architecture on Building Web-Based Information System," in Islam Zeitschrift Für Geschichte Und Kultur Des Islamischen Orients, 2010, vol. 2010, no. Snati, pp. 47-50.

[20] R. S. Pressman, Software Engineering: A Practitioner's Approach, 7th ed. New York: McGraw-Hill, 2011.

[21] I. Sommerville, Software Engineering. 2010.

[22] A. Rosa and M. Shalahuddin, Rekayasa Perangkat Lunak. Bandung: Informatika, 2013.

[23] K.-J. Yang and R. Pooley, "Process modelling to support the Unified Modelling Language," in Computer Software and Applications Conference, 1997. COMPSAC '97. Proceedings., The Twenty-First Annual International, 1997, pp. 467-472.

[24] D. K. Kim, "Development of Mobile Cloud Applications using UML," Int. J. Electr. Comput. Eng., vol. 8, no. $1,2018$.

[25] J. Bloomberg, "The Agile Architecture Revolution: How Cloud Computing", REST-based SOA, and mobile computing are changing enterprise I. Hoboken, New Jersey: Canada: John Wiley \& Sons, Inc, 2013.

[26] R. Yuliana and B. Rahardjo, "Designing An Agile Enterprise Architecture for Mining Company by Using TOGAF Framework," in Proceedings of 2016 4th International Conference on Cyber and IT Service Management, CITSM 2016, 2016

[27] N. Sharma and M. Wadhwa, "eXSRUP: Hybrid Software Development Model Integrating Extreme Programing", Scrum \& Rational Unified Process. 2015.

[28] A. Kaur and K. Kaur, "Effort Estimation in Traditional and Agile Mobile Application Development \& Testing," Indones. J. Electr. Eng. Comput. Sci., vol. 12, no. 3, 2018.

[29] J. A. McCall, P. K. Richards, and G. F. Walters, "Factors in Software Quality - Volume 1 - Concept and Definitions of Software Quality," Def. Tech. Inf. Cent., 1977.

[30] T. Wahyuningrum and K. Mustofa, "A Systematic Mapping Review of Software Quality Measurement: Research Trends, Model, and Method," Int. J. Electr. Comput. Eng., vol. 7, no. 5, p. 2847, 2017.

[31] H. Y. Suhendi, M. A. Ramdhani, and F. S. Irwansyah, "Verification Concept of Assesment for Physics Education Student Learning Outcome," Int. J. Eng. Technol., vol. 7, no. 3.21, pp. 321-325, 2018.

[32] I. H. Al-Asqalani, Bulughul Al-Maram, Terjemah oleh A.Hasan. Bangil: Pustaka Tamam, 1997.

[33] S. Sabiq, Figh As-Sunnah. Bandung: PT. Al Maarif, 1978.

[34] M. Ja'far, Tuntunan Ibadah Zakat, Puasa, Haji. Jakarta: Kalam Mulia, 2001.

[35] Y. Al-Qardhawi, Hukum Zakat, Studi Komparatif mengenai Status dan Filsafat Zakat berdasarkan Qur'an Hadis. Jakarta: Litera AntarNusa dan Mizan, 1996.

[36] Anonymous, “Cara Menentukan Zakat Hasil Pertanian, Buah-buahan, Bunga dan Sayuran,” Zakat.or.id, 2012. .

[37] Jamaluddin, Problematika Harta dan Zakat. Jakarta: Kencana, 2007.

[38] Anonymous, "Zakat Profesi," dompetdhuafa.org. .

[39] Anonymous, "Ketentuan Wajib Zakat Hewan Ternak," suaramuslim.net, 2017.

\section{BIOGRAPHIES OF AUTHORS}

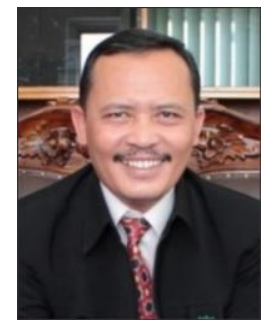

Ah.Fathonih is an associate professor in Department of Islamic Law at the UIN Sunan Gunung Djati Bandung, Indonesia. His current research interests focus on Islamic Law especially in the field Halal Law, Islamic Banking, Islamic Economic, and Zakah. 


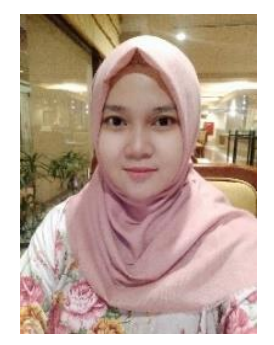

Dian Sa'adillah Maylawati is a lecturer in Department of Informatics at the UIN Sunan Gunung Djati Bandung, Indonesia. Her current research interests focus on Software Engineering, Expert System, Text Mining, and Natural Language Processing. She takes Ph.D degree of Information and Communication Technology in Universiti Teknikal Malaysia Melaka (UTeM).

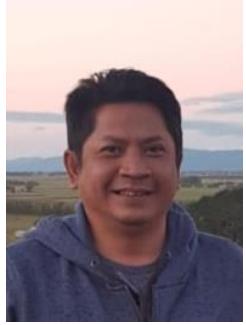

Muhammad Ali Ramdhani is a professor in Information Technology Research in Department of Informatics at the UIN Sunan Gunung Djati Bandung, Indonesia. His current research interests focus on Information System, Expert System, Decision Support System, Strategic Management, and Research Methodology. 